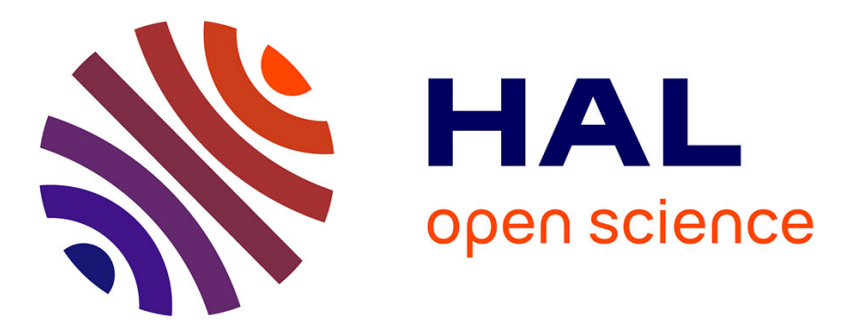

\title{
Genetic structure of endangered wild grapevine Vitis vinifera ssp. sylvestris populations from Tunisia: Implications for conservation and management
}

Néjia Zoghlami, Leila Riahi, Valerie Laucou, Ahmed Mliki, Labdelwahed Ghorbe, Patrice This

\section{To cite this version:}

Néjia Zoghlami, Leila Riahi, Valerie Laucou, Ahmed Mliki, Labdelwahed Ghorbe, et al.. Genetic structure of endangered wild grapevine Vitis vinifera ssp. sylvestris populations from Tunisia: Implications for conservation and management. Forest Ecology and Management, 2013, 310, pp.896-902. 10.1016/j.foreco.2013.09.039 . hal-01137191

\section{HAL Id: hal-01137191 \\ https://hal.science/hal-01137191}

Submitted on 30 Mar 2015

HAL is a multi-disciplinary open access archive for the deposit and dissemination of scientific research documents, whether they are published or not. The documents may come from teaching and research institutions in France or abroad, or from public or private research centers.
L'archive ouverte pluridisciplinaire HAL, est destinée au dépôt et à la diffusion de documents scientifiques de niveau recherche, publiés ou non, émanant des établissements d'enseignement et de recherche français ou étrangers, des laboratoires publics ou privés. 


\title{
Genetic structure of endangered wild grapevine Vitis vinifera ssp. sylvestris populations from Tunisia: Implications for conservation and management
}

\author{
Néjia Zoghlami ${ }^{\mathrm{a}, *}$, Leila Riahi ${ }^{\mathrm{a}}$, Valérie Laucou ${ }^{\mathrm{b}}$, Ahmed. Mliki $^{\mathrm{a}}$, Abdelwahed Ghorbel ${ }^{\mathrm{a}}$, Patrice This ${ }^{\mathrm{b}}$ \\ ${ }^{a}$ Centre de Biotechnologie de Borj-Cédria, Laboratoire de Physiologie Moléculaire des Plantes, BP 901, Hammam-Lif 2050, Tunisia \\ ${ }^{\mathrm{b}}$ Equipe DAVEM, UMR AGAP 1334, INRA SupAgro, 2 Place Pierre Viala, 34060 Montpellier, France
}

\section{A R T I C L E I N F O}

\section{Article history:}

Received 8 May 2013

Received in revised form 14 September 2013

Accepted 19 September 2013

Available online 14 October 2013

\section{Keywords:}

Vitis sylvestris

SSRs

Population differentiation

Isolation by distance

Conservation

\begin{abstract}
A B S T R A C T
Wild grapes, considered as the putative ancestor of the cultivated form, represent the only endemic taxon of the Vitaceae in Europe and the Maghreb. The species has become highly threatened because of habitat loss and intensive forest exploitation.

In this work, we analyzed genetic aspects that could shed light on the evolution and conservation of wild grapes that still be found in forests along river banks in Tunisia. We examined the genetic structure of twenty populations using 10 nuclear SSR loci. Vitis sylvestris has a high level of genetic variation with $84.5 \%$ of the loci assayed being polymorphic, a mean number of alleles of 10.4 , and a mean heterozygosity per population of 0.7546 . We calculated Wright's FST statistic to estimate gene flow indirectly and to evaluate whether or not there was genetic structuring among populations. We found a marked differentiation among populations according to FST values and clustering. AMOVA has shown that most of the variation was partitioned between rather than among populations. A significant pattern of isolation by distance was found which implies that each population would constitute a distinct pool of genetic variation that warrants conservation.

Finally, the exponential curve of the relationship between genetic distances and demographic data strongly suggests that due to populations' small sizes and fragmentation, $V$. sylvestris is actually at high risk of extinction in Tunisia. Therefore, all studied populations are valuable for conservation.
\end{abstract}

(c) 2013 Elsevier B.V. All rights reserved.

\section{Introduction}

Vitis vinifera L. is the most widely cultivated and economically important fruit crop in the world (Mattia et al., 2008). The species includes the cultivated form ( $V$. vinifera ssp. sativa) and the wild form ( $V$. vinifera ssp. sylvestris). Currently, most botanists regard the wild ancestral grape Vitis sylvestris as the primitive form of the cultivated grape because of the close morphological resemblance and free gene flow between them (Heywood and Zohary, 1991) and consequently have reduced its taxonomic status to subspecies level within the $V$. vinifera crop complex (Levadoux, 1956). This subspecies represents the only endemic taxon of the Vitaceae in Europe and the Maghreb (Heywood and Zohary, 1991). According to This et al. (2006), it can be argued that differences between the two subspecies are the result of the domestication process.

Based on phylogeographic approach, the presence and diffusion of chloroplast haplotypes in the eastern regions of the Mediterranean area suggested the Caucasian region as the most likely centre

\footnotetext{
* Corresponding author. Tel./fax: +216 79325738 .

E-mail address: zoghlami_n@yahoo.fr (N. Zoghlami).
}

of origin of wild grapevine (Grassi et al., 2006). V. vinifera subsp. sylvestris was abundant from the Atlantic coast of Europe to Tajikistan and the western Himalayas, as well as in northern Africa until the nineteenth century (Lacombe et al., 2003).

Extensive anthropogenic habitat alteration and introduction of downy mildew, powdery mildew and phylloxera from North America during the second part of the 19th century have led to population loss and decline (Arnold et al., 1998). The present distribution of the wild grapevine is highly fragmented, in disjoint micro-populations or metapopulations, with few individuals. Presently, wild plants are restricted to small isolated populations along riverbank forests (Arnold et al., 1998; Zohary and Hopf, 2000). As a result, modern wild grapevines are endangered and threatened with extinction (Arnold et al., 2005). The future of the current $V$. vinifera subsp. sylvestris populations represents a major stake in biodiversity conservation (Terral et al., 2010). Indeed, V. vinifera subsp. silvestris, is a unique and valuable genetic resource for the improvement of cultivated grapevines regarding their genetic tolerance to salinity (Raymond et al., 2008), their resistance to many virus diseases and their high adaptation potential to different soil types and climates (Ocete et al., 1995; Arnold et al., 
1998). Therefore, the conservation of genetic diversity of wild germplasm of economic species such as grapevine is important to ensure the potentialities of wild populations' use in future breeding programs of the domesticated cultivars. As domestication is an evolutionary process where strong selections for specific traits, combined with a series of population bottlenecks, greatly alter the genetic structure of populations and the underlying genetic architecture of phenotypic traits, modern, elite varieties of many crops have low to no genetic variation within cultivars (Pusadeea et al., 2009). Thus, potentially useful traits may be lost in grapevine cultivars, thereby reducing the set of phenotypes that can subsequently be used by plant breeders for crop improvement. In this context, the frequent paucity of new traits in grapevine germplasm collections has lead to increased efforts to conserve wild relatives of domesticated plants, as a reservoir of phenotypes for future crop improvement. Wild germplasm provide reservoir of useful trait and makes them particularly important sources of germplasm for breeding programs.

Based on these considerations, the objectives of the present study were to analyze genetic relationships among Tunisian wild grapevine populations prospected from the different regions of the subspecies' range in Tunisian forests in order to examine the level of genetic diversity of this germplasm, its genetic structure and probable evidence of isolation by distance. Results will provide baseline information for the development of suitable conservation strategies for better management of wild grapevine germplasm in Tunisia.

\section{Materials and methods}

\subsection{Plant material}

This study is based on 58 grapevine wild accessions subdivided onto 20 populations selected as representatives of the distribution range of the subspecies $V$. vinifera ssp. sylvestris in Tunisia. The analyzed accessions were discriminated based on several traits including mainly the mating system (flower sex; OIV. 151) which is the most discriminating criterion between the wild and the cultivated grapes. In fact, wild grapevines are dioecious (sex separate: either male or female (Zoghlami et al., 2003) while cultivated accessions are hermaphrodite. The general shape (OIV. 079) and the opening/ overlapping of the petiolar sinus of mature leaves (OIV. 079-1) were also described (Zoghlami, 2007). For instance, wild grapes possessed a $U$ shaped petiolar sinus opening, whereas leaves of Tunisian cultivated grapes were characterized by overlapping petiolar sinus. The habitat preference was also considered since wild accessions grow in humid soils, while cultivars prefer dry habitats (Zoghlami et al., 2003). The wild grapevine accessions have also been collected and are grown ex situ in a greenhouse in the CBBC centre.

Origin, sample size and geographical characteristics for the sampled populations of Tunisian wild grapes are presented in Table 1.

\subsection{Molecular analysis}

DNA was isolated from young leaves frozen in liquid nitrogen and ground in a mortar according to the protocol for DNeasy Plant Mini Kit (Qiagen, Hilden, Germany). PCR amplifications were performed in $20 \mu \mathrm{l}$ reactions consisting of $2.25 \mathrm{mM} \mathrm{MgCl} 2,250 \mu \mathrm{M}$ of each dNTP, 10 pmol of each primer, 1x PCR buffer, $0.5 \mathrm{U}$ of Taq DNA polymerase (Qiagen), and 20 ng DNA. PCR conditions were 35 cycles of a 1 min denaturation at $94{ }^{\circ} \mathrm{C}$, a $1 \mathrm{~min}$ annealing at $56{ }^{\circ} \mathrm{C}$, and a 2 min extension at $72{ }^{\circ} \mathrm{C}$. Electrophoresis was carried out using an automated ABI PRISM 3100 DNA capillary sequencing apparatus (Applied Biosystems) running GENESCAN software through ABI PRISM ${ }^{\circledR} 3100$ GA POP 4TM.

A total of 10 nuclear SSR loci were selected: VVS2 (Thomas and Scott, 1993), VVMD5, VVMD7, VVMD21, VVMD24, VVMD27, VVMD28, VVMD32 (Bowers et al., 1996, 1999), and VVIP60 and VVIP31 for their position on 10 different linkage groups (AdamBlondon et al., 2004). Four of these markers (VVS2, VVMD5, VVMD7 and VVMD27) have been chosen as a core set for the screening of grapevine collections in Europe (This et al., 2004).

\subsection{Data analysis}

All estimates were made based on ten microsatellite loci. We obtained allele and genotype mean number, observed and expected heterozygosities and genetic identities using identity 4.0 software (Wagner and Sefc, 1999).

Fixation indices (Wright, 1965) for each locus and population were determined using POPGENE 1.32 (Yeh et al., 1995). Gene flow $(\mathrm{Nm}$ ) was estimated according to (Whitlock and McCauley, 1999). Mean $\mathrm{Nm}$ value was used to obtain indirect estimates of effective population size per neighborhood ( $\mathrm{Nb}$; Slatkin and Barton, 1989).

The component of within and between population diversity was estimated using AMOVA analysis of Arlequin ver. 3.5 software (Excoffier and Lischer, 2010).

Isolation by distance was analyzed with the method proposed by Slatkin (1993). Thus, gene flow $(\log (F S T /(1-F S T))$ was plotted against the geographic distances $\log (\mathrm{km})$.

To describe the genetic relationships among populations, the UPGMA derived dendrogram (Sneath and Sokal, 1973) was obtained using the matrix of pair-wise FSt values loaded in Darwin software (5.0.148 version; available through: http:// darwin.cirad.fr/darwin). The reconstructed tree was used to describe the demographic status of the species as proposed by Moritz (1996) for conservation studies. This method is easily applied if phylogenetic relations among populations can be established. It is based on the idea that expanding populations are expected to show a star-like phylogeny that would result in a parabolic relation between the genetic distance and the logarithm of the size of the populations following the UPGMA analysis. On the contrary, stable populations would show a strongly structured phylogeny and would result in an exponential relationship.

To support the considerations made on genetic exchange, population structure and isolation by distance within wild grapes, a Bayesian analysis using STRUCTURE version 2.3.3 (Pritchard et al., 2000; Kumar et al., 2009) was also performed following the admixture model with a burnin of 50,000 and a number of MCMC repetitions of 50,000. The objective was to test the hypothesis of the genetic distinctiveness of the studied populations.

\section{Results}

\subsection{Genetic polymorphism}

For the accessions under study, all 10 tested SSRs generated multiple fragments. The number of alleles ranged from 6 (VVMD5) to 17 (VVMD28) with a total of 104 alleles and an average of 10.4 alleles per locus. The number of observed genotypes ranged from 11 (VVMD21, VVMD5) to 24 (VVMD28) with an average of 17.4 and a total of 174 (Table 2). The expected heterozygosity varied between 0.621 (VVIP60) and 0.855 (VVS2). Except VVMD28, VVIP60, VVMD24 and VVMD7 loci, observed heterozygosity was lower than expected indicating heterozygote deficiency across Tunisian wild grapes in the other studied loci. 
Table 1

Origin, sample size and geographical characteristics for the sampled populations of Tunisian wild grapes (Vitis sylvestris ssp).

\begin{tabular}{|c|c|c|c|c|c|c|c|c|}
\hline Numeric code & Population name & Sample size & Ecosystem & $\begin{array}{l}\text { Elevation } \\
\text { in m.a.s.l }\end{array}$ & $\begin{array}{l}\text { Region of } \\
\text { sampling }\end{array}$ & $\begin{array}{l}\text { Interval of } \\
\text { latitude-longitude }\end{array}$ & $\begin{array}{l}\text { Dispersal area per } \\
\text { population in } \mathrm{m}^{2}\end{array}$ & $\begin{array}{l}\text { Population } \\
\text { position }\end{array}$ \\
\hline 1 & Bellif & 13 & Forest & 72 & North-west & $37^{\circ} 01^{\prime} 53^{\prime \prime} \mathrm{N} 90^{\circ} 05^{\prime} 57^{\prime \prime} \mathrm{E}$ & 100 & Alluvial \\
\hline 2 & Balta station 1 & 6 & Mountain & 501 & North-west & $36^{\circ} 42^{\prime} 31^{\prime \prime} \mathrm{N} 8^{\circ} 56^{\prime} 34^{\prime \prime} \mathrm{E}$ & 100 & Colluvial \\
\hline 3 & Balta station 2 & 5 & Mountain & 500 & North-west & $36^{\circ} 42^{\prime} 31^{\prime \prime} \mathrm{N} 8^{\circ} 56^{\prime} 34^{\prime \prime} \mathrm{E}$ & 100 & Colluvial \\
\hline 4 & Chitana & 1 & Mountain & 450 & North & $37^{\circ} 08^{\prime} 51^{\prime \prime} \mathrm{N} 90^{\circ} 05^{\prime} 25^{\prime \prime} \mathrm{E}$ & 100 & Colluvial \\
\hline 5 & Djebba & 7 & Mountain & 750 & North-west & $36^{\circ} 40^{\prime} 00^{\prime \prime} \mathrm{N} 9^{\circ} 00^{\prime} 00^{\prime \prime} \mathrm{E}$ & 100 & Colluvial \\
\hline 6 & Ghar el Melh & 3 & Plain & 60 & North & $37^{\circ} 09^{\prime} 00^{\prime \prime} \mathrm{N} 10^{\circ} 09^{\prime} 00^{\prime \prime} \mathrm{E}$ & 100 & Alluvial \\
\hline 7 & Hamri oujdadine & 1 & Plain & 50 & North-west & $37^{\circ} 05^{\prime} 19^{\prime \prime} \mathrm{N} 90^{\circ} 01^{\prime} 00^{\prime \prime} \mathrm{E}$ & 100 & Alluvial \\
\hline 8 & Jbal Semaa & 1 & Mountain & 500 & North & $37^{\circ} 12^{\prime} 13^{\prime \prime} \mathrm{N} 9^{\circ} 27^{\prime} 24^{\prime \prime} \mathrm{E}$ & 100 & Colluvial \\
\hline 9 & Kef el Hamem & 1 & Forest & 387 & North-east & $36^{\circ} 51^{\prime} 38^{\prime \prime} \mathrm{N} 10^{\circ} 47^{\prime} 32^{\prime \prime} \mathrm{E}$ & 100 & Colluvial \\
\hline 10 & Khedhayria & 2 & Mountain & 150 & North-west & $36^{\circ} 55^{\prime} 53^{\prime \prime} \mathrm{N} 84^{\circ} 47^{\prime} 07^{\prime \prime} \mathrm{E}$ & 100 & Colluvial \\
\hline 11 & Khelij Ben Yahia & 2 & Forest & 250 & North-west & $36^{\circ} 57^{\prime} 12^{\prime \prime} \mathrm{N} 84^{\circ} 46^{\prime} 09^{\prime \prime} \mathrm{E}$ & 100 & Alluvial \\
\hline 12 & Mhibes & 2 & Plain & 40 & North & $37^{\circ} 15^{\prime} 43^{\prime \prime} \mathrm{N} 9^{\circ} 27^{\prime} 36^{\prime \prime} \mathrm{E}$ & 100 & Alluvial \\
\hline 13 & Mimene & 1 & Plain & 150 & North & $37^{\circ} 11^{\prime} 10^{\prime \prime} \mathrm{N} 9^{\circ} 27^{\prime} 20^{\prime \prime} \mathrm{E}$ & 100 & Alluvial \\
\hline 14 & Ouchtata & 3 & Plain & 70 & North-west & $36^{\circ} 58^{\prime} 00^{\prime \prime} \mathrm{N} 90^{\circ} 01^{\prime} 00^{\prime \prime} \mathrm{E}$ & 100 & Alluvial \\
\hline 15 & Oum Abid & 1 & Plain & 30 & North-west & $37^{\circ} 06^{\prime} 23^{\prime \prime} \mathrm{N} 90^{\circ} 01^{\prime} 55^{\prime \prime} \mathrm{E}$ & 100 & Alluvial \\
\hline 16 & Tebaynia & 2 & Mountain & 550 & North-west & $36^{\circ} 45^{\prime} 00^{\prime \prime} \mathrm{N} 84^{\circ} 45^{\prime} 00^{\prime \prime} \mathrm{E}$ & 100 & Colluvial \\
\hline 17 & Tebaba & 2 & Forest & 100 & North-west & $36^{\circ} 54^{\prime} 00^{\prime \prime} \mathrm{N} 90^{\circ} 07^{\prime} 00^{\prime \prime} \mathrm{E}$ & 100 & Colluvial \\
\hline 18 & Touajnia & 1 & Plain & 150 & North-west & $37^{\circ} 12^{\prime} 25^{\prime \prime} \mathrm{N} 94^{\circ} 41^{\prime} 07^{\prime \prime} \mathrm{E}$ & 100 & Alluvial \\
\hline 19 & Ziatine & 1 & Forest & 450 & North-west & $37^{\circ} 13^{\prime} 13^{\prime \prime} \mathrm{N} 91^{\circ} 13^{\prime} 32^{\prime \prime} \mathrm{E}$ & 100 & Colluvial \\
\hline 20 & Zouaraa & 3 & Forest & 40 & North-west & $36^{\circ} 59^{\prime} 1^{\prime \prime} \mathrm{N} 8^{\circ} 59^{\prime} 13^{\prime \prime} \mathrm{E}$ & 100 & Colluvial \\
\hline
\end{tabular}

Table 2

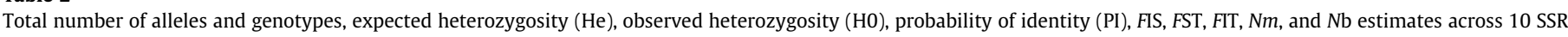
primers in 20 wild grapevine populations from Tunisia.

\begin{tabular}{|c|c|c|c|c|c|c|c|c|c|c|}
\hline SSR & Alleles & Genotypes & $\mathrm{He}$ & Ho & PI & Fis & Fit & Fst & $\mathrm{Nm}$ & $\mathrm{Nb}$ \\
\hline VVMD28 & 17 & 24 & 0.778 & 0.79 & 0.071 & -0.58963 & 0.1089 & 0.43943 & 0.3189 & 2.0026 \\
\hline VVMD27 & 10 & 20 & 0.668 & 0.62 & 0.102 & -0.15738 & 0.27372 & 0.37248 & 0.4211 & 2.6445 \\
\hline VVMD21 & 10 & 11 & 0.742 & 0.37 & 0.374 & -0.54738 & 0.14856 & 0.44975 & 0.3058 & 1.9204 \\
\hline VVIP60 & 8 & 13 & 0.621 & 0.68 & 0.166 & -0.38299 & 0.12507 & 0.36736 & 0.4305 & 2.7035 \\
\hline VVMD5 & 6 & 11 & 0.829 & 0.48 & 0.153 & -0.23602 & 0.4133 & 0.52533 & 0.2258 & 1.418 \\
\hline VVIP31 & 12 & 19 & 0.833 & 0.6 & 0.08 & -0.08762 & 0.29927 & 0.35573 & 0.4527 & 2.8429 \\
\hline VVMD32 & 12 & 23 & 0.773 & 0.77 & 0.076 & -0.14818 & 0.1102 & 0.22503 & 0.8609 & 5.4064 \\
\hline VVMD24 & 8 & 18 & 0.778 & 0.86 & 0.107 & -0.18802 & 0.0439 & 0.12131 & 1.8108 & 11.3718 \\
\hline VVS2 & 10 & 17 & 0.855 & 0.81 & 0.094 & -0.46461 & 0.05045 & 0.35167 & 0.4608 & 2.8938 \\
\hline VVMD7 & 11 & 18 & 0.791 & 0.87 & 0.102 & -0.36005 & 0.07864 & 0.20691 & 0.9583 & 6.0181 \\
\hline Mean & 10.4 & 17.4 & 0.76 & 0.68 & 0.134 & $(-0.40343$ to -0.20372$)$ & $(0.05010-0.23748)$ & $(0.25577-0.41064)$ & 0.62456 & 3.9222 \\
\hline
\end{tabular}

Number of observed alleles, expected heterozygosity and PI values indicate VVMD28 as the most informative marker and VVMD21 as the least informative (Table 2).

The probability of sampling identical genotypes (PI) varied between 0.071 for VVMD28 and 0.374 for VVMD21 locus and the overall probability of genetic identity (IC) was $4.86 \times 10^{-10}$, indicating a high discriminating power of the analyzed microsatellite markers (Table 2). Markers VVMD28, VVMD32 and VVIP31 proved to be sufficient to discriminate all varieties. These loci gave good discrimination values with the probabilities of identical genotypes of $0.071,0.076$ and 0.080 , respectively (Table 2 ).

\subsection{Population structure}

Primers varied in their ability to detect variation at within population level. The within populations Ho varied from $37 \%$ for VVMD21 primer to $87 \%$ for VVMD7 (Table 2). On average over all primers, the population with the smallest sample size (population 15 ) exhibited the lowest level of within-population genetic diversity (mean HO 0.4159), while the other populations displayed mean $\mathrm{H} 0$ ranging between 0.4852 and 1.1348 (Table 3). Population 1 with the highest size was the most variable (mean H0 1.1348).

Per population, percentage of polymorphic loci varied from $60 \%$ (population 20) to $100 \%$ (populations $1,5,11$ and 18), with a mean value of $84.5 \%$. Observed heterozygosity varied from 0.5333 (Population 20) to 0.9 (populations $4,9,10,13$ and 17), with an average of 0.75 , and expected heterozygosity ranged between 0.3867 (population 20) and 1 (population 18), with an average of 0.6648 .

Except FIS values, all Wright's $F$ statistics for polymorphic loci were positive and significantly ( $P$ 0.01; Table 2$)$ different from zero. The mean FIS value is quite low $(-0.316$, with a $99 \%$ confidence interval from $(-0.40343$ to -0.20372$)$ ), which suggests that on average there is an excess of heterozygotes. FST values were very heterogeneous (0.121-0.525; Table 2) with an average value of 0.34 . That is, $34 \%$ of the genetic variation is explained by differences among populations. All FST values were significantly different from zero. Therefore, many of the values obtained for FIT are due to differences among populations. FIT values ranged from 0.0439 to 0.299 , with a mean of 0.165 and a confidence interval between 0.05010 and $0.23748(P, 0.05)$. Gene flow $(\mathrm{Nm})$ estimates ranged between 0.2258 and 1.8108 (average 0.62456), which suggests that there is relatively little genetic exchange among $V$. sylvestris populations. Effective neighborhood size ( $\mathrm{Nb}$; Slatkin and Barton, 1989) was moderate (1.418 to 11.3718 , with a mean of 3.9222), suggesting that few individuals are contributing allelic variants and that gene flow may be insufficient to prevent differentiation among populations (Table 2).

This moderate differentiation was best displayed by the UPGMA FST derived dendrogram (Fig. 1) on which, population 6 was released as the most differentiated from the others and populations $4,7,8,9,13,15,18$ and 19 , with the smallest sample sizes were the least differentiated ones. 
Table 3

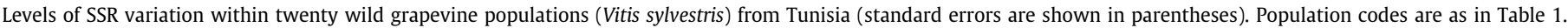

\begin{tabular}{|c|c|c|c|c|}
\hline \multirow[t]{2}{*}{ Population } & \multicolumn{2}{|c|}{ Proportion of observed } & \multirow[t]{2}{*}{ Expected heterozygosity (mean) } & \multirow[t]{2}{*}{ Index of genotypic diversity (Ho) } \\
\hline & Polymorphic loci & Heterozygosity (mean) & & \\
\hline 1 & 100 & $0.5769(0.2027)$ & $0.6062(0.1906)$ & $1.1348(0.3832)$ \\
\hline 2 & 70 & $0.55(0.4846)$ & $0.3879(0.2928)$ & $0.5469(0.4430$ \\
\hline 3 & 90 & $0.76(0.3239)$ & $0.5489(0.2172)$ & $0.7767(0.3884)$ \\
\hline 4 & 90 & $0.9(0.3162)$ & $0.9(0.3162)$ & $0.6238(0.2192)$ \\
\hline 5 & 100 & $0.6857(0.3857)$ & 0.4967 (0.1839) & $0.7807(0.3080)$ \\
\hline 6 & 80 & $0.7(0.4289)$ & $0.4733(0.2503)$ & $0.5663(0.3043)$ \\
\hline 7 & 80 & $0.8(0.4216)$ & $0.8(0.4216)$ & $0.5545(0.2923)$ \\
\hline 8 & 70 & $0.7(0.4830)$ & $0.7(0.4830)$ & $0.4852(0.3348)$ \\
\hline 9 & 90 & $0.9(0.3162)$ & $0.9(0.3162)$ & $0.6238(0.2192)$ \\
\hline 10 & 90 & $0.9(0.3162)$ & $0.6(0.2108)$ & $0.6238(0.2192)$ \\
\hline 11 & 100 & $0.8(0.2582)$ & $0.8(0.2331)$ & $1.0351(0.3950)$ \\
\hline 12 & 80 & $0.7(0.4216)$ & $0.6333(0.3668)$ & $0.784(0.49630)$ \\
\hline 13 & 90 & $0.9(0.3162)$ & $0.9(0.3162)$ & $0.6238(0.2192)$ \\
\hline 14 & 90 & $0.8333(0.3239)$ & $0.58(0.2201)$ & $0.7398(0.3110)$ \\
\hline 15 & 60 & $0.6(0.5164)$ & $0.6(0.5164)$ & 0.4159 (0.3579) \\
\hline 16 & 80 & $0.6(0.3944)$ & $0.5833(0.3536)$ & $0.7232(0.4672)$ \\
\hline 17 & 90 & $0.9(0.3162)$ & $0.6000(0.2108)$ & $0.6238(0.2192)$ \\
\hline 18 & 100 & $1(0.0000)$ & $1(0.0000)$ & $0.6931(0.0000)$ \\
\hline 19 & 80 & $0.8(0.4216)$ & $0.8(0.4216)$ & $0.5545(0.2923)$ \\
\hline 20 & 60 & $0.5333(0.4766)$ & $0.3867(0.3411)$ & $0.5000(0.4545)$ \\
\hline Average & 84.5 & 0.7546 & 0.6648 & \\
\hline
\end{tabular}

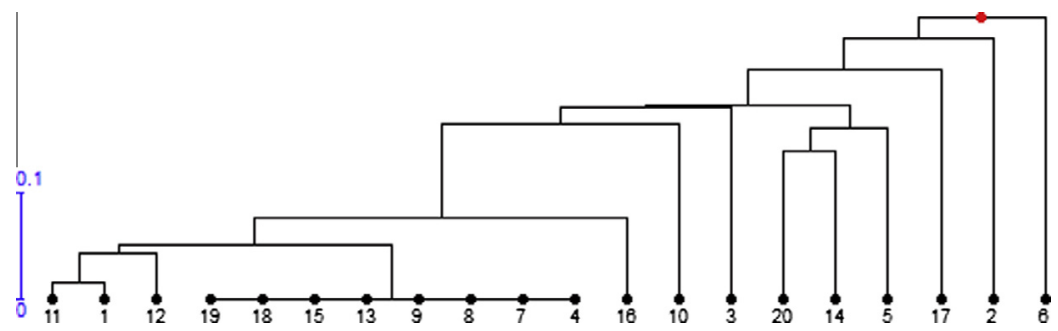

Fig. 1. UPGMA derived dendrogram of the 20 wild grapevine populations based on the pair-wise FST values (population names are given in Table 1).

Table 4

AMOVA analysis for the twenty wild grapevine populations using 10 SSR primers

\begin{tabular}{|c|c|c|c|c|}
\hline $\begin{array}{l}\text { Source of } \\
\text { variation }\end{array}$ & d.f. & $\begin{array}{l}\text { Sum of } \\
\text { squares }\end{array}$ & $\begin{array}{l}\text { Variance } \\
\text { components }\end{array}$ & Variation (\%) \\
\hline Intra-population & 19 & 176.886 & $1.17^{* * *}$ & 29.43 \\
\hline Inter-population & 96 & 271.338 & $2.82^{* * *}$ & 70.57 \\
\hline Total & 115 & 448.224 & & \\
\hline
\end{tabular}

${ }^{* * * *} P<0.001$.

The variance components of within and between populations detected with AMOVA were $29.43 \%$ and $70.57 \%$ of the total variance, respectively, which were both significant $(p<0.001$ ) (Table 4 ). It seems clear that while most of the variation is partitioned between populations, there is still considerable variation within populations.

\subsection{Evidence for isolation by distance pattern in wild grapes}

The tests for isolation by distance (IBD) are more clear-cut with the log-transformed data. Thus, to illustrate the relationship between gene flow and geographic distance, log [(FST/(1-FST)] was plotted against $\log (\mathrm{km})$ according to Slatkin (1993) (Fig. 2). Despite from the low coefficient of determination $\left(R^{2}=0.0214\right)$, the regression line $(y=0.311 x)$ shows a significant relationship between gene flow and geographic distance. That is, increasing exchange of genes between populations grows in close proximity and little gene flow occurs between geographically distant populations,

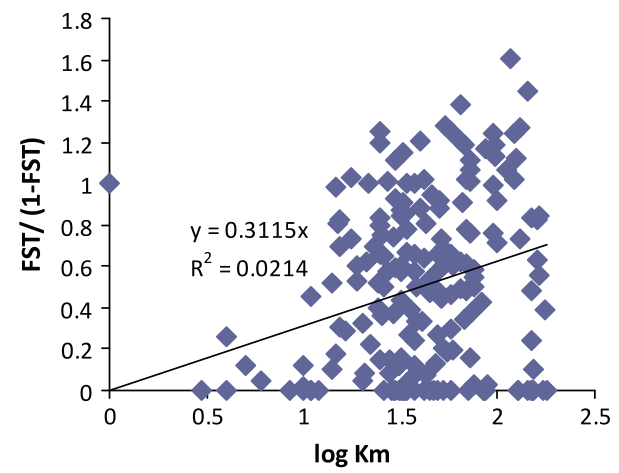

Fig. 2. Gene flow (log $(F S T /(1-F S T))$ versus geographic distances $(\log (\mathrm{km}))$ of 20 Tunisian wild grapevine populations.

as proposed for natural populations by the isolation-by-distance model (Slatkin, 1993).

Conversely, values of FST/(1-FST) ranged from a null value of 0 to a moderate value of 1.2809 , averaging 0.5129 , which also indicated moderate gene flow between the twenty studied wild grapevine populations (data not shown).

Estimated population structure of wild grapes and surface population using STRUCTURE (Pritchard et al., 2000; Kumar et al., 2009) for $K=20$ (Fig. 3) have shown that the most distinct populations were $2,3,5,6,14,17$ and 20 (Table 1 ). In accordance to cluster analysis, the latter were also released as the most differentiated ones when based upon the Fst derived dendrogram (Fig. 1). 


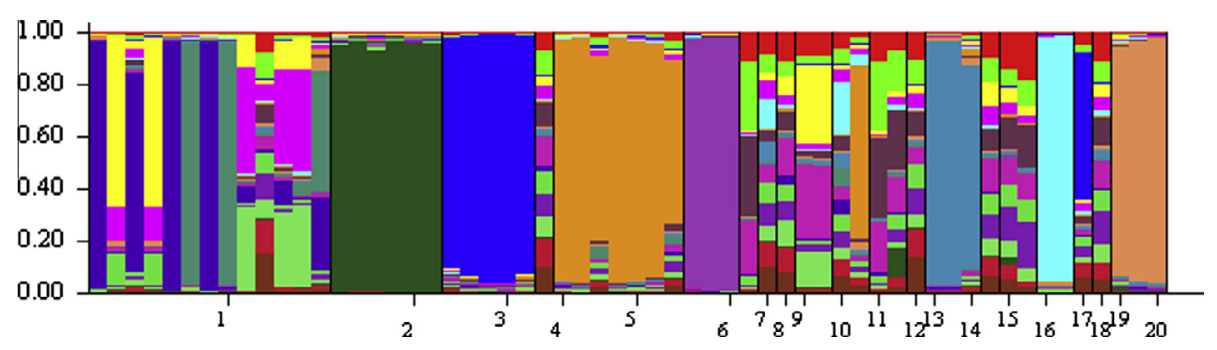

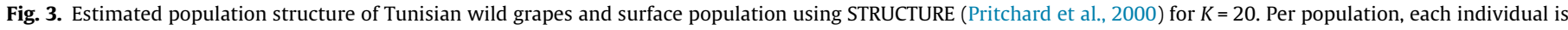

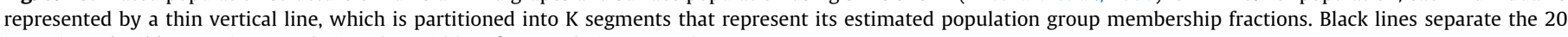
investigated wild grapevine populations (see Table 1 for population names).

For the remaining populations, they do not seem to derive from the hybridization of the former populations, since per population, each individual is represented by a thin vertical line which is partitioned into $K$ segments (that represent its estimated population group membership fractions) shaded by other different colors each. Hence, the hypothesis of the occurrence of private admixture patterns per each wild grapevine population can be forwarded and the isolation by distance model can therefore be supported.

\section{Discussion}

Currently, wild grapevines (V. sylvestris) are endangered throughout all their distribution range (Di Vecchi-Staraz et al., 2009), and conservation efforts are required to maintain the genetic integrity and survival of the remnant populations. Within this context, in the present study, our aim was to apply population genetics methods to decipher the population structure in $V$. sylvestris. The first goal was to use recently developed microsatellite markers (Zoghlami et al., 2009) to characterize the genetic diversity and structure in wild grapes and the second was to assess the relationship between geographic and genetic (FSTS) distances in order to determine whether or not there was an isolation by distance pattern (IBD). The information on the amount and distribution of wild grapevine genetic diversity would guide various plans for the setting up of rational conservation strategies.

\subsection{Genetic variation and structure}

Nuclear microsatellite markers are frequently used to estimate genetic variation in cultivated grapes (Grassi et al., 2008), but have rarely been applied in the study of wild plants, although unlinked microsatellites are informative as far as they represent independent chromosomal markers.

We expected that $V$. sylvestris with small and fragmented populations would have low levels of genetic variation. However, it shows genetic variation levels close to those found for cultivated grapes (Zoghlami et al., 2009). Mean allele number per locus (10.4) is comparable to values found in V. sylvestris (Grassi et al., 2008), though $V$. sylvestris is neither wide-ranging nor with large population sizes. Expected heterozygosity (0.76) also falls within the range of values calculated for wild grapes (Grassi et al., 2008).

The mean FIS value was quite low $(-0.316)$ and suggests that on average there is an excess of heterozygotes. Besides, FST and FIT values indicate that $34 \%$ of the genetic variation is explained by differences among populations. The average Gene flow $(\mathrm{Nm})$ estimate (0.62456) suggests that there is relatively little genetic exchange among $V$. sylvestris populations and the moderate effective neighborhood size ( $\mathrm{Nb}$; Slatkin and Barton, 1989) implies that few individuals are contributing allelic variants and that gene flow may be insufficient to prevent differentiation among populations (Table 2).
The aforementioned low gene flow was also revealed between the wild grapevine populations analyzed here and the set of Tunisian autochthonous grapevine cultivars (61 cv.) previously genotyped by the same 10 nSSR markers (Zoghlami et al., 2009) while searching for possible parent-off-spring relationships (Zoghlami, 2007). The unsuccessful characterization of parentage between both grapevine sub-species, though old and extinct cultivars were included in this study may be due to physical barriers between both grapevine compartments. Indeed, wild grapes occur in natural closed landscape of forests, whereas the cultivated forms occur very far from the former. Therefore, there seems to be less correlation between reproductive success (gene flow) and distance. Even so, conservation efforts should focus on the remnant populations of wild grapevine to maintain their genetic integrity as well as their survival. In fact, maintenance of allelic richness especially rare alleles must be prioritized because these genotypes may harbor rare characteristics being potentially useful for breeding purposes or for the identification of molecular markers associated to particular environmental adaptations as well as some resistances to crop diseases.

Conversely, $V$. sylvestris has significant levels of genetic differentiation, with $70.57 \%$ of the total variation due to differences between populations, as shown by AMOVA. This is consistent with the findings from other analyses of woody plant populations showing that considerable genetic diversity is partitioned between, rather than among populations (Turpein et al., 2001).

The mean FST values found for wild grapes are within the range of values reported for species with discontinuous distributions where topography could act as a natural barrier to gene flow (Grassi et al., 2008).

\subsection{Genetic relations and isolation by distance}

The isolation by distance analysis clearly shows a significant pattern, suggesting that the distribution of genetic variation is explained by the geographic distances separating the populations (Fig. 2). The three populations (1, 11 and 12) with the highest levels of genetic variation (highest index of genotypic diversity $\mathrm{H} 0$; Table 3) formed one group (Fig. 1). The rest of the populations formed a second group and include the ones with the least genetic variation values.

The reduced population sizes and geographic isolation might underlie the observed genetic structure. Therefore, one historical scenario may account for our results. Here, genetic differentiation would depend on the low gene flow levels, population sizes, and the degree of geographical isolation; a particular spatial genetic structure, called the isolation by distance (IBD) pattern. Indirect estimates of dispersal, based on population genetics, provide several means to test for IBD (Rousset, 1997; Smouse and Peakall, 1999; Hardy and Vekemans, 1999; Fenster et al., 2003), namely by testing the null hypothesis of increasing population genetic differentiation with geographic distance (Epperson et al., 1999). In the 


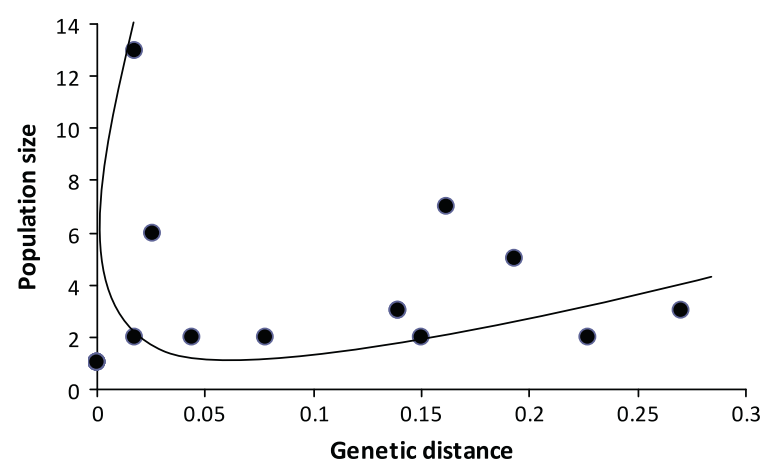

Fig. 4. Population sample sizes versus genetic distance estimates for Tunisian wild grapes following Moritz (1996).

absence of selection, departure from the IBD pattern may indicate stochastic dispersal processes resulting either in a panmictic unit, where intense random gene flow tends to erase population differentiation (Zeller et al., 2004),

In nature, isolation by distance (IBD) is often observed in natural plant species where the likelihood of gene flow is inversely related to distance (Grassi et al., 2008). It is the result of limited gene flow, where the probability of gene flow between 2 populations is a function of the geographical distance between them (Slatkin, 1993).

Our results on the overall pattern of genetic differentiation conform to isolation by distance model (Fig. 2). Therefore, due to geographic barriers, each of the studied populations would constitute an independent source of genetic variation and a distinct gene pool that warrants conservation.

\subsection{Conservation implications}

The information available warrants two management and conservation strategies. The first one would consist of an in situ conservation plan that would define core areas completely free from perturbation for at least the most genetically diverse populations (namely populations $1(\mathrm{H} 0=1.1348)$ and $11(\mathrm{H} 0=1.0351)$. This would guarantee the maintenance of most of the species' genetic variation, Nevertheless, FST values suggest that except populations $4,7,8,9,13,15,18$ and 19 , with the smallest sample sizes, all remaining others are important for conservation because they are differentiated. Conservation plans for wild species should also consider demographic traits of populations such as population sizes (Moritz, 1996). In that respect, we present a simple analysis (Fig. 4) to get an insight about $V$. sylvestris historical demography. It is based on the idea that expanding populations are expected to show a star-like phylogeny (Moritz, 1996) that would result in a parabolic relation between the genetic distance, determined following the UPGMA analysis and the sample size of populations. On the contrary, stable populations would show a strongly structured phylogeny and would result in an exponential relationship. Our results show that since the curve is exponential, $V$. sylvestris populations have decreased historically. These results highlight the importance of man produced habitat fragmentation that has affected this endangered species by changing both its demography and its genetic structure and thus it appears as the most critical aspect for an in situ conservation strategy. The second management strategy aims towards ex situ conservation via the establishment of wild grapevine nurseries and national collections that should preserve all studied populations. The genetic and demographic analyses of this study strongly suggest that due to the small size and population fragmentation of the populations, $V$. sylvestris is actually at risk of extinction. An encouraging fact is that proposals for the establishment of areas free of anthropogenic perturbation have been made by the government forestry officials. However, due to the information gathered in this study, the ex situ conservation still be urgently recommended.

\section{Acknowledgments}

This work was supported in part by grants from the Tunisian Ministry of Research and the French Ministry of Research program "Centre de Ressources Biologiques."

\section{References}

Adam-Blondon, A.F., Roux, C., Claux, D., Butterlin, G., Merdinoglu, D., This, P., 2004. Mapping 245 SSR markers on the Vitis vinifera genome: a tool for grape genetics. Theor. Appl. Genet. 109, 1017-1027.

Arnold, C., Gilett, F., Gobat, J.M., 1998. Situation de la vigne sauvage Vitis vinifera L. ssp. sylvestris (Gmelin) Hegi en Europe. Vitis 37, 159-170.

Arnold, C Schnitzler, A Douard, A Peter, R. Gillet, F, 2005. Is there a future for wild grapevine (Vitis vinifera subsp. silvestris) in the Rhine Valley? Biodiver. Conser. 14, 1507-1523.

Bowers, J.E., Dangl, G.S., Vignani, R., Meredith, C.P., 1996. Isolation and characterization of new polymorphic simple sequence repeat loci in grape (Vitis vinifera L.). Genome 39, 628-633.

Bowers, J.E., Dangl, G.S., Meredith, C.P., 1999. Development and characterization of additional microsatellite DNA markers for grape. Am. J. Enol. Viticult 50 (3), 243-246.

Di Vecchi-Staraz, M., Laucou, V., Bruno, G., Lacombe, T., Gerber, S., Borse, T., Boselli, M., This, P., 2009. Low level of pollen-mediated gene flow from cultivated to wild grapevine: consequences for the evolution of the endangered subspecies Vitis vinifera L. subsp. silvestris. J. Hered. 100, 66-75.

Epperson, B.K., Huang, Z., Li, T.Q., 1999. Measures of spatial structure in samples of genotypes for multiallelic loci. Genetic 73, 251-261.

Excoffier, L., Lischer, H.E.L., 2010. Arlequin suite ver 3.5: a new series of programs to perform population genetics analyses under Linux and Windows. Mol. Ecol. Res. 10, 564-567.

Fenster, C.B., Vekemans, X., Hardy, O.J., 2003. Quantifying gene flow from spatial genetic structure data in a metapopulation of Chamaecrista fasciculate (Leguminosae). Evolution 57, 995-1007.

Grassi, F., Labra, M., Imazio, S., 2006. Phylogeographical structure and conservation genetics of wild grapevine. Conserv. Genet. 7, 837-845.

Grassi, F., De Mattia, F., Zecca, G., Sala, F., Labra, M., 2008. Historical isolation and Quaternary range expansion of divergent lineages in wild grapevine. Biol. J. Linn. Soc. 95, 611-619.

Hardy, O.J., Vekemans, X., 1999. Isolation by distance in a continuous population: reconciliation between spatial autocorrelation and population genetics models. Heredity 83, 145-154.

Heywood, V., Zohary, D., 1991. A catalogue of wild relatives of cultivated plants native to Europe. Flor. Mediter. 5, 375-415.

Kumar, S., Skjæveland, A., Orr, R.J.S., Enger, P., Ruden, T., Mevik, B., Burki, F., Botnen, A., Shalchian-Tabrizi, K., 2009. AIR: a batch-oriented web program package for construction of supermatrices ready for phylogenomic analyses. BMC Bioinformatics 10, 357.

Lacombe, T., Laucou, V., Di Vecchi, M., Bardenave, L., Bourse, T., Siret, R., David, J., Boursiquot, J.M., Bronner, A., Merdinoglu, D., This, P., 2003. Inventory and characterization of Vitis vinifera ssp. sylvestris in France. Acta Hort. 603, 553557.

Levadoux, L., 1956. Les populations sauvages de Vitis vinifera L.. Annales de l'Amélioration des Plantes 6, 59-118.

Mattia, F., Imazio, S., Grassi, F., Doulati, H., Scienza, A., Labra, M., 2008. Study of genetic relationships between wild and domesticated grapevine distributed from Middle East regions to European countries. Rendicon. Linc. 19, 223-240.

Moritz, C., 1996. Uses of molecular phylogenies for conservation. In: Harvey, P.H., Leigh Brown, A.J., Maynard Smith, J., (Eds.), New uses for new phylogenies. Oxford University Press, pp. 203-216.

Ocete, R., Del Tío, R., Lara, M., 1995. Les parasites des populations de la vigne sylvestre, Vitis vinifera sylvestris (Gmelin) Hegi, des Pyrénées Atlantiques (France). Vitis 34 (3), 191-192.

Pritchard, J.K., Stephens, M., Donnelly, P., 2000. Inference of population structure using multilocus genotype data. Genetics 155, 945-959.

Pusadeea, T., Sansanee, J., Yu-Chung C., Benjavan, R., Barbara, A.S., 2009. Genetic structure and isolation by distance in a landrace of Thai rice. PNAS. <http:// www.pnas.org_cgi_doi_10.1073>.

Raymond, W.M., Fung, M.G., Csaba, F., Laszlo, G.K., Yan, H., Marsh, E., McIntyre, L.M., Schachtman, D.P., Wenping, Q., 2008. Powdery mildew induces defenseoriented reprogramming of the transcriptome in a susceptible but not in a resistant grapevine. Plant Physiol. 146 (1), 236-249.

Rousset, F., 1997. Genetic differentiation and estimation of gene flow from Fstatistics under isolation by distance. Genetics 145, 1219-1228.

Slatkin, M., 1993. Isolation by distance in equilibrium and non-equilibrium populations. Evolution 47, 264-279. 
Slatkin, M., Barton, N.H., 1989. A comparison of three indirect methods for estimating average levels of gene flow. Evolution 43, 1349-1368.

Smouse, P.E., Peakall, R., 1999. Spatial autocorrelation analysis of individual multiallele and multilocus genetic structure. Heredity 82, 561-573.

Sneath, P.A., Sokal, R.R., 1973. Numerical taxonomy. W. H. Freeman, San Francisco. CA.

Terral, J.F., Tabard, E., Bouby, L., Ivorra, S., Pastor, T., Figueiral, I., Picq, S., Chevance J.B., Jung, C., Fabre, L., Tardy, C., Compan, M., Bacilieri, R., Lacombe, T., This, P., 2010. Evolution and history of grapevine (Vitis vinifera) under domestication: new morphometric perspectives to understand seed domestication syndrome and reveal origins of ancient European cultivars. Annal. Bot. 105, 443-455.

This, P., Jung, A., Boccacci, P., Borrego, J., Botta, R., Costantini, L., Crespan, M., Dangl, G.S., Eisenheld, C., Ferreira Monteiro, F., Grando, S., Ibanez, J., Lacombe, T., Laucou, V., Magalhaes, R., Meredith, C.P., Milani, N., Peterlunger, E., Regner, F., Zulini, L., Maul, E., 2004. Development of a standard set of microsatellite reference alleles for identification of grape cultivars. Theor. Appl. Genet. 109, $1448-1458$.

This, P., Lacombe, T., Thomas, M., 2006. Historical origins and genetic diversity of wine grapes. Trend. Genet. 22, 511-519.

Thomas, M.R., Scott, N.S., 1993. Microsatellite repeats in grapevine reveal DNA polymorphisms when analyzed as sequence tagged sites (STSs). Theor. Appl. Genet. 86, 985-990.

Turpein, T., Tehola, T., Manninen, O., Nevo, E., Nissila, E., 2001. Microsatellite diversity associated with ecological factors in Hordeum spontaneum populations in Israel. Mol. Ecol. 10, 1577-1591.
Wagner, H.W., Sefc, K.M., 1999. IDENTITY 4.0. Centre for Applied Genetics, University of Agricultural Sciences, Vienna.

Whitlock, M., McCauley, D.E., 1999. Indirect measures of gene flow and migration: Fst $\neq 1(4 \mathrm{Nm}+1)$. Heredity $82,117-125$.

Wright, S., 1965. The interpretation of population structure by F-statistics with special regard to systems of mating. Evolution 19, 395-420.

Yeh, F.C., Chong, D.K.X., Yang, R.C., 1995. RAPD variation within and among natura populations of trembling aspen (Populus tremuloides) from Alberta. J. Hered. 86, 454-460.

Zeller, K.A., Bowden, R.L., Leslie, J.F., 2004. Population differentiation and recombination in wheat scab populations of Gibberella zeae from the United States. Mol. Ecol. 13, 563-571.

Zoghlami, N., 2007. Utilisation des marqueurs moléculaires pour l'évaluation génétique de la vigne tunisienne. Ph. D dissertation, University El-Manar Tunis Tunisia. 198 pp.

Zoghlami, N., Mliki, A., Ghorbel, A., 2003. Occurrence and discrimination of spontaneous grapes native to Tunisia by RAPD markers. Acta Hort. 603, $157-$ 165.

Zoghlami, N., Riahi, L, Laucou, V., Lacombe, T, Mliki, A, Ghorbel, A., This, P., 2009. Origin and genetic diversity of Tunisian grapes as revealed by microsatellite markers. Sci. Hort. 120, 478-486.

Zohary, D., Hopf, M., 2000. Domestication of plants in the old world: the origin and spread of cultivated plants in West Asia, Europe, and the Nile Valley, third ed. New York, Oxford University. 